\title{
Perception versus Performance Indicators: A Study of Innovation Performance in a Research University
}

\author{
Tan Owee Kowang ${ }^{1}$, Choi Sang Long ${ }^{2}$, Amran Rasli $^{3}$ \& Goh Chin Fei ${ }^{1}$ \\ ${ }^{1}$ Faculty of Management, Universiti Teknologi Malaysia, Johor, Malaysia \\ ${ }^{2}$ International Business School, Universiti Teknologi Malaysia, Kuala Lumpur, Malaysia \\ ${ }^{3}$ Innovation and Commercialisation Center, Universiti Teknologi Malaysia, Johor, Malaysia \\ Correspondence: Owee Kowang Tan, T08, Faculty of Management, Universiti Teknologi Malaysia, 81310, Johor \\ Bahru, Johor, Malaysia. Tel: 6-012-789-1560. E-mail: oktan@utm.my
}

Received: March 23, 2015 Accepted: August 3, 2015 Online Published: December 21, 2015

doi:10.5539/ass.v12n1p24 URL: http://dx.doi.org/10.5539/ass.v12n1p24

\begin{abstract}
Research Universities in Malaysia are continually strengthening the innovation process with the ultimate aim to improve innovation performance. However, innovation improvement effort requires prior recognition by individual involved that there is need for improvement prior to the execution. Hence, based on performance indicators released by one of Research University in Malaysia, the study identified a Faculty with a relatively low innovation performance, and assesses the innovation performance level perceived by the members of the Faculty. As such, 5 innovation performance measures are identified from literature review and transformed into a survey questionnaire which responded by 62 respondents. Descriptive analysis is performed to rank the perceived innovation performance level and subsequently compared with performance indicators. The research findings present an interesting managerial implication; respondents perceived that innovation performance is maintained at the same level for last 2 years despite performance indicator reflected a decline trend. This issue needs to be addressed for the reason that to achieve desired innovation performance, it is important to have the right employee perception.
\end{abstract}

Keywords: innovation, innovation performance, perceived performance, performance indicators, research university

\section{Introduction}

\subsection{Research Background}

Research Universities in Malaysia have been viewed as the source of new innovation development. As such, to enhance research output and strengthen innovation performance, various Research Alliances have been established in Research Universiy (RU). Research Alliance is a strong and formal association that formed by a group of research individual, professors, laboratories and centers of excellence within RU, as well as external parties' base on the area of expertise (KRA, 2013). One of the main objectives for Research Alliance is to assist RU towards reaching RU criteria's in Research and Publication.

This study focuses on a RA in one of RU within Malaysia, namely Knowledge Based Research Alliance (KRA). KRA consist of 35 research groups from 10 faculties. In KRA, performance of research groups are measured through two categories of performance indicators, which are number of Principle Investigator within the research groups and amount of Research Funding granted (RF) by the research groups.

Principle Investigator (PI) is defined as the individual who assigned by an organization that responsible for the management and completion of a research project. While Research Funding granted (RF) refers to the "financial assistance mechanism that provides money, property, or both to an eligible entity to carry out an approved project or activity."

However, innovation performance figures released by KRA in term of PI and RF for year 2010 to 2012 shown an obvious warning trend. In particular RF for year 2012, which is achieved only $41 \%$ of the target and $114 \%$ lower than the preceding year. Further analysis on performance figure revealed that performance of research groups from one of the faculty (namely Faculty M) was relatively low with RF performance of nearly zero. Hence, it is 
crucial to identify improvement opportunity within KRA research groups, with particular focus on Faculty M (FM).

\subsection{Problem Statement}

Continuous improvement on research and innovation should be seen as a dynamic capability in RU. However, individual who involved in the improvement activities must agree and recognized there is a need for improvement prior to the implementation of improvement program.

According to Ropeik (2012), individual tends to less worry and afraid of risk and threat than the indicator warns. Hence, study on how individual perceive the performance versus respond to actual performance indicator is an area that need further explore prior to exploration of improvement opportunity. As such, this study is conducted to assess innovation performance level that perceived by researchers within FM KRA's research groups versus performance indicators prior to the exploration of potential innovation and research improvement opportunity within KRA in FM. If gap between perception and indicator does exist, the roots of the perception-indicators gap must be further investigate and address prior to the execution of improvement activities.

\section{Literature Review}

Organizational innovation performance facilitates organization performance and subsequently poses the organization toward a stronger competitive advantages position in the global competitive market (Raymond \& St-Pierre, 2010). Studies done by prior researches, Saleh \& Wang (1993), Panne, Beers \& Kleinknecht (2003), Hartmann (2006), Lee \& Change (2006), Byers, Dorf \& Helson (2011) suggested that Organizational innovation performance (OIP) is positively correlated with organization performance. Hence, OIP is recognized broadly as effective tools to growth organizational performance and to ensure the organization stay survived in global competitions.

Wide ranges of indicators had been proposed by prior researches Saleh \& Wang (1993), Panne, Beers, \& Kleinknecht (2003), Hartmann (2006), Lee \& Change (2006) as innovation performance measures for research based organization. As a whole, the measurement of OIP proposed by prior researches can be grouped into four categorized, which are (1) performance measures that indicates financial success, such as amount of research funding granted, expenditures of research project and organization's profit. (2) Performance measure that manifests research or technical achievement, for instance numbers of new project or product or services completed per year. (3) Performance measure that reflects external parties acceptance or linkages, for example market share, number of external linkages and (4) Performance measure that exhibits effectiveness of innovation process such as product development cycle and time-to-market.

Table 1. Organization Innovation Performance (OIP) Measures

\begin{tabular}{|c|c|}
\hline $\begin{array}{l}\text { Organization Innovation Performance } \\
\text { (Proposed measure in this research) }\end{array}$ & Sources: \\
\hline $\begin{array}{l}\text { a) Efficiency and effectiveness of innovation process. } \\
\text { (Research project is more efficient and effectively managed than previous } 2 \text { years). }\end{array}$ & $\begin{array}{l}\text { Saleh \& Wang } \\
\text { (1993); Griffin \& } \\
\text { Page (1996); }\end{array}$ \\
\hline $\begin{array}{l}\text { b) Number of new project, services or product completed. } \\
\text { (Number of new research projects that completed is higher than previous } 2 \text { years). }\end{array}$ & $\begin{array}{l}\text { Panne et al. } \\
\text { (2003); Wong } \\
\text { (2005); } \\
\text { Hartmann } \\
\text { (2006) } \text { Lee \& }\end{array}$ \\
\hline $\begin{array}{l}\text { c) Research fund granted. } \\
\text { (Amount of research fund granted is higher than previous } 2 \text { years). }\end{array}$ & $\begin{array}{l}\text { Chang (2006); } \\
\text { Raymond \& }\end{array}$ \\
\hline $\begin{array}{l}\text { d) Number of external links. } \\
\text { (Number of collaboration and cooperation with external parties is greater than } \\
\text { previous } 2 \text { years). }\end{array}$ & $\begin{array}{l}\text { St-Pierre (2010); } \\
\text { Liao \& Rice } \\
\text { (2010); Byers et } \\
\text { al. (2011). }\end{array}$ \\
\hline $\begin{array}{l}\text { e) Time to complete a project. } \\
\text { (Time spent to complete a research project is shorter than previous } 2 \text { years). }\end{array}$ & \\
\hline
\end{tabular}

An effective measurement of OIP should not focus solely on single category of performance measure but should contain multidimensional measurement variables (Griffin \& Page, 1996). As such, amass finding from previous 
researchers; this research extracted five assessment measures as OIP indicators base on the research nature of the faculty, which include measure on efficiency and effectiveness of innovation process, measure on number of new project or product completed, number of find granted, number of external links and time to complete a project. In addition, in this study, the perceived innovation performance levels are assessed by the perceived comparison of innovation performance level at the point the survey is conducted versus last 2 years (Brcar \& Lah, 2011; Tohidi et al., 2012). The 5 OIP measures are summarized in Table 1.

The OIP performance measures employed in this research comprise of the broader aspect of measurement, which includes assessment of project or/and research achievement (number of new project, service or product completed/developed); measurement of innovation performance in terms of financial aspects (research funding), effectiveness of innovation management (time to complete a project; effectiveness of innovation process), and measurement of external parties engagement (number of external link).

\section{Research Methodology}

\subsection{Population and Sampling}

The population for this study is the group of lecturers from the faculty (FM) who are the member of KRA. Based on the list of KRA members published at KRA official website, there is a total of 108 KRA members that originated from FM. Base on sampling table of Krejcie \& Morgan (1970), the appropriate sampling size for this study is 86 .

\subsection{Researcg Instrument}

A quantitative tool in the form survey questionnaire is used as research instrument for this study. The questionnaire contains 10 questions and was divided into two sections. Section A intends to to collect demographic backgroundof of respondents. Section B attempts to grade respondents perceived innovation performance based on the 5 innovation performance indicators identified from literature review. For the convenience of respondents, the questionnaire was design in a table format and selection of the answer which involves tick (/) the standard rating that provided in the table base on five points scale.

\subsection{Descrptive Analysis}

Descriptive statistic analysis provides a very basic summary of each variable by showing a proportionate breakdown of the categories for each variable (Henn, Weinstein, \& Foard, 2006). Descriptive statistics involves processing and manipulation of raw data, and subsequently transform it into a finding that represents the situation for the set of factors (Sekaran, 2003). The descriptive statistical analysis tool in term of mean is used in this study to assess the central tendency of response from survey questionnaire in term of level of innovation performance. The measurement represents an overall picture of the data and the interpretation of the means score is based on proposal by Weiers (2008) as shown in Table 2 .

Table 2. Interpretation of Overall Mean $(\mu)$

\begin{tabular}{ll}
\hline Overall Mean $(\mu)$ & Interpretation \\
\hline $1.0 \leq \mu<1.5$ & Strongly Disagree \\
$1.5 \leq \mu<2.5$ & Disagree \\
$2.5 \leq \mu<3.5$ & Neutral \\
$3.5 \leq \mu<4.5$ & Agree \\
$4.5 \leq \mu \leq 5.0$ & Strongly Agree \\
\hline
\end{tabular}

\section{Data Analysis}

\subsection{Reliavility Test}

A total of 108 questionnaires had been distributed with 62 responded, this made up the overall respond rate of 57\%. Cronbach Alpha reliability values for the 5 innovation performance measures are ranged from 0.8102 to 0.8972. This implies that the data is statistically significant to proceed for further analysis. Cronbach Alpha reliability value of greater than 0.60 is suggested to be adequate for testing the reliability of factors (Mol \& Birkinshaw, 2009). 


\subsection{Descriptive Analysis}

The respondents' perceptions of innovation performance for FM are retrieved from section B of research survey questionnaire. The individual score across the 5 innovation performance meausres were averaged up according to the respective innovation performance measure. Table 3 summarizes the mean scores of the five NPD performance measures in descending order, with the overall mean of 3.4. Innovation performance attributes "Efficiency and effectiveness of innovation process" and "Number of new project, service or product, completed" scored the highest and similar mean of 3.70. "Time spent on completion of innovation project" is rated as the lowest performance attribute at performance level of 3.20. The rest of innovation performance attributes, i.e. "Research fund granted" and "Number of external linkages" are suggested by respondent's attained performance of 3.30 .

Table 3. Organization Innovation Performance (OIP) Measures

\begin{tabular}{|c|c|}
\hline Innovation Performance attributes (Measureised in the research) & Mean \\
\hline $\begin{array}{l}\text { 1. Efficiency and effectiveness of innovation process } \\
\text { (Research project is more efficient and effectively managed than previous } 2 \text { years). }\end{array}$ & 3.70 \\
\hline $\begin{array}{l}\text { 2. Number of new project, services or product completed } \\
\text { (Number of new research projects that completed is higher than previous } 2 \text { years) }\end{array}$ & 3.70 \\
\hline $\begin{array}{l}\text { 3. Research fund granted } \\
\text { (Amount of research fund granted is higher than previous } 2 \text { years). }\end{array}$ & 3.30 \\
\hline $\begin{array}{l}\text { 4. Number of external links } \\
\text { (Number of collaboration and cooperation with external parties is greater than previous } 2 \\
\text { years). }\end{array}$ & 3.30 \\
\hline $\begin{array}{l}\text { 5. Time to complete a project } \\
\text { (Time spent to complete a research project is shorter than previous } 2 \text { years). }\end{array}$ & 3.20 \\
\hline Overall mean & 3.40 \\
\hline
\end{tabular}

\section{Discussion and Conclusion}

The overall perceived level of innovation performance among members of KRA's research groups within FM is at "Neutral" level of 3.4. The remarkable finding from the analysis result is respondents hold a neutral (i.e. between agree and disagree) stand on 3 out of the 5 performance measures, which are "Amount of research fund granted is higher than previous 2 years"; "Number of collaboration and cooperation with external parties is greater than previous 2 years." and "Time spent to complete a research project is shorter than previous 2 years". However, respondents agreed that "Research project is more efficient and effectively managed than previous 2 years" and "Number of new research projects that completed is higher than previous 2 years".

A neutral stand toward "Amount of research fund grant is higher than previous 2 years" perhaps is due to the high competition among researchers on acquiring research funding. Statistic from the Malaysia Science and Technology Information Center (STI) reveals that there are 6,338 experts or researchers in the top 10 institutions within Malaysia recorded in National Minimum Data Set (NMDS). Hence, researchers in RU are working under a high competitive environment; contend among each other as well as compete with researchers from other Research Universities to secure financial support via research funding. As such, during the process of research grant application, on top of complying the basic research fund application criteria, such as scientific merit, technical merit, research competence and high impact research; researchers are also need to ensure that their research proposal is exceptional outstanding when compare with others researchers.

The neutral stand on relationship with external party and time spent on completing a research project is another alerting outcome. One of the objectives of KRA is to enhance research output and strengthen innovation performance via formation of alliances with external parties' base on the area of expertise. Finding from this study apparently is not in aligned with KRA's objective. In addition, prior research (Mol \& Birkinshaw, 2009; Zeng, Xie \& Tam, 2010) also revealed that collaboration and cooperation with external parties is crucial because it not only widen the organization's access toward external capital resource, new technology, but also speed-up overall research process and reduce overall research expenses.

The overall perceived innovation performance of 3.40 (neutral) suggested that respondents regard innovation performance in KRA research groups within FM is maintained at the same level for past 2 years, which is not in 
line with performance indicator released by KRA that showing a decline on overall performance. Particularly, for the perceived innovation performance in term of number of project completed, which is found not in parallel with indicator released by KRA in term of number of principle investigator. Theoretically, the increase on number of project completed should be subsequently reflected in the growth of number of principle investigator. From the study, respondents agreed or perceived that number of project completed is higher than last 2 years, however, figure released by KRA revealed that number of PI in 2012 is lower than 2011. The difference between the perceive performance level and KAI perhaps could be explained by study done by Dennison \& Terry (2014) which found that individual (researchers) normally have different point of view when compared with an organization (KRA). According to Ropeik (2012), perception of risk can never be rational perfectly, however, this issue needs to be addressed because in order to achieve desired organizational outcome in term of innovation performance, it is important to have not only the right practices but the right employee perception of those practices and performance.

According to Picken (2006), perception refers to an individual's interpretation of stimuli under confronted environment based on past experiences. Perception and reality might possibly significantly alter, but perception and attitudes are closely associated. Pickon (2006) propose a "Step-by-step process for changing attitudes in the workplace" which consists of 7 steps of assessing, adjusting and resolving perception gap for a positive working environment. The 7 steps process proposed by Pickon (2006) could be potentially applied by KRA in the effort to reduce the perception-indicator gap of innovation performance.

\section{Acknowledgments}

Authors wish to acknowledge the Malaysian Ministry of Higher Education and Universiti Teknologi Malaysia under the Research Grant (Vote No. 4F323) for sponsoring this publication.

\section{References}

Brcar, F., \& Lah, S. (2011). Innovation Management and an Innovative Ideas System. Organizacija, 44, 3-10. http://dx.doi.org/10.2478/v10051-011-0001-1

Byers, T. H., Dorf, R. C., \& Nelson, A. J. (2011). Technology Ventures From Idea to Enterprise. New York: McGraw-Hill.

Terry, D. (2014). Critical Success Factors of Technological Innovation and Diffusion in Higher Education. Middle-Secondary Education and Instructional Technology Dissertations. Paper 118.

Griffin, A., \& Page, A. (1996). PDMA Success Measurement Project: Recommended Measure for Product Development Success and Failure. Journal of Product Innovation Management, 13(6), 478-496.

Hartmann, A. (2006). The role of organizational culture in motivating innovative behaviour in construction firms. Construction Innovation, 6(3), 159-172. http://dx.doi.org/10.1111/1540-5885.1360478

Henn, M., Weinstein, M., \& Foard, N. (2006). A Short Introduction to Social Research. London: Sage Publications Ltd.

Krejcie, R. V., \& Morgan, D. W. (1970). Determining Sample Size for Research Activities. Edu and Psychological Measurement, 30, 607-610. http://dx.doi.org/10.1177/001316447003000308

Lee, Y., \& Chang, H. (2006). Leadership style and innovation ability: an empirical study of Taiwanese wire and cable companies. Journal of American Academy of Business, 9(2), 218-223.

Mol, M., \& Birkinshaw, J. (2009). The sources of management innovation: When firms introduce new management practices. Journal of Business Research, 26(12), 269-1280.

Panne, G. v., Beers, C. v., \& Kleinknecht. (2003). A Success and Failure of Innovation: A Literature Review. International Journal of Innovation Management, 7(3), 309-338.

Pickens, J. (2006). Perceptions and Attitudes of Individuals. In N. Borkowski (Ed.), Organizational Behavior in Health Car.e NY: Jones \& Barlett Publishing. "Book of the Year Awards: The Most Valuable Texts of 2005, as chosen by AJN's panel of judges." AJN, American Journal of Nursing, 106(1), 51-57.

Rasli, A. (2006). Data analysis and beyond: A practical guide for post-graduate social scientists. Skudai, Malaysia: Penerbit UTM.

Raymond, L., \& St-Pierre J. (2010). R\&D as a determinant of innovation in manufacturing SMEs: An attempt at empirical clarification. Technolovation, 30(1), 48-56.

Ropeik, D. (2012). The Perception Gap: Recognizing and managing the risks that arise when we get risk wrong, 
Food and Chemical Toxicology, 50(5), 1222-1225.

Saleh, S. D., \& Wang, C. K. (1993). The Management of Innovation: Strategy, Structure, and Organizational Climate. IEEE Transactions on Engineering Management, 40(1), 14-21.

Sekaran, U. (2003). Research Methods for Business A Skill Building Approach. USA: John Wiley \& Sons.

Tohidi, H., Seyedaliakbar, S. M., \& Mandegari, M. (2012). Organizational learning measurement and the effect on firm innovation. Journal of Enterprise Information Management, 25(3), 219-245.

UTM K-Economy Research Alliances. (2013, August 19). Fact and Figures. Retrieved August 19, 2013, from http://www.k-economy.utm.my/fact-and-figures/

Weiers, R. M. (2008). Introduction to Business Statistics (6th ed.). United States: Thomson South-Western.

Zeng, S., Xie, X., \& Tam, C. (2010). Relationship between cooperation networks \& innovation performance of SMEs. Technovation, 30(3), 181-194.

\section{Copyrights}

Copyright for this article is retained by the author(s), with first publication rights granted to the journal.

This is an open-access article distributed under the terms and conditions of the Creative Commons Attribution license (http://creativecommons.org/licenses/by/3.0/). 